\title{
Kajian Bentuk dan Makna Simbolik Figurin Gerabah Majapahit (Periode Hayam Wuruk 1350-1389 M)
}

\author{
Anne Susannawaty \\ Program Magister Desain - FSRD ITB
}

\begin{abstract}
The earthware figurines of Majapahit were clay-based artworks from the Majapahit Kingdom (1350-1389 AD) of Trowulan at Mojokerto, East Java. The name "majapahit" itself refers to the known great kingdom that unite "nusantara" (covering Malay peninsula, Sumatra, Java, Bali, Borneo, Celebes, up North to the Southern of Phillipine). Having exposed to the varieties and highquality of earthware figurines of Majapahit from the Trowulan site, the study looks into their symbolic shapes and meanings which was known to be heavily influenced by Hinduism. To address this issue, the study applied qualitativedescriptive method by means of visual analysis. Study on clay-objects' shapes was carried out to explore the associated meanings of 4 (four) figurine groups: (1) male figurines, (2) female figurines, (3) child figurines, and (4) deformedface figurines. Results indicate that shapes of the object cater their symbols and associated meanings to the way religion and/or beliefs were held. Figure of gods, kings, and the nobles were made to manifest values (truth, heroism, devotion, and loyalty). Yet, although Hinduism was the most associated values to appear on the objects, Budhism were also identified.This shows that earthware figurines of Majapahit were product of acculturation where different values are met, explored, and exposed to appease the spirits (dharma) through ritual and performance.
\end{abstract}

Keywords: figurine; meaning; symbolic shape.

\section{Pendahuluan}

Trowulan sebagai bekas ibu kota kerajaan Majapahit merupakan situs yang terbesar dan terdapat banyak sisa peninggalan bersejarah. Berbagai bukti tinggalannya berupa artefaktual, monumen, karya sastra dan cerita rakyat (folklore) [1]. Situs Trowulan dengan luas $\pm 100 \mathrm{~km}^{2}$ merupakan sebuah daerah kecamatan yang berada di wilayah Kabupaten Mojokerto, letaknya kurang lebih $13 \mathrm{~km} \mathrm{ke}$ arah Jombang. Di situs Trowulan terdapat pula peningalanpeninggalan gerabah dan terakota. Temuan gerabah dari situs Trowulan beraneka ragam jenisnya, dari segi kualitas dan kuantitas menunjukkan tingkat yang tinggi. 
Gerabah Majapahit pada masa Hayam Wuruk mencapai puncak perkembangannya dan menghasilkan benda-benda peralatan kehidupan yang memuat nilai-nilai estetika, simbolik dan fungsional. Temuan fragmen gerabah dapat dikelompokkan menjadi jenis wadah, bukan wadah dan komponen bangunan. Jenis wadah terdiri dari mangkuk, cawan, buli-buli, cepuk. Jenis temuan bukan wadah terdiri dari tungku, lampu minyak, figurin dan miniatur bangunan. Sedangkan jenis komponen bangunan terdiri dari genteng, hiasan atap, memolo, pipa saluran air, ubin, kemuncak, dan sebagainya. Gerabah dijadikan perlengkapan berbagai macam upacara yang berhubungan dengan kepercayaan masyarakat. Gerabah dianggap memiliki nilai religi yang sangat tinggi. Dalam upacara penguburan pada masyarakat prasejarah, gerabah sering dipakai sebagai bekal kubur (burial-gift) atau sebagai wadah kubur yang disebut 'kubur tempayan' (jar burial). Gerabah dianggap penting dan dapat dipakai sebagai bekal perjalanan maupun bekal bagi kehidupan di alam yang lain.

Dalam perkembangannya terdapat gerabah dalam bentuk figurin yang berfungsi sebagai sarana upacara keagamaan dalam rangka pelaksanaan upacara pitrayajna (upacara untuk leluhur). Figurin bisa merupakan gambaran atau perwujudan roh nenek moyang juga sebagai alat permainan anak-anak atau boneka dalam seni pertunjukan. Terutama dalam tokoh-tokoh yang dikenal dalam cerita Panji, pendeta/pertapa (Bubuksah) dan panakawan, yang dijadikan sebagai boneka, baik untuk permainan anak-anak atau sebagai alat peraga dalam membawakan cerita tertentu.

Yang menarik untuk dijadikan penelitian dari benda-benda kerajinan gerabah tradisional di Trowulan, adalah unsur-unsur bentuk dan makna simbolik sebagai benda-benda kehidupan sehari-hari maupun benda-benda sakral/upacara. Benda-benda gerabah tersebut perlu dikaji karena penggalian unsur-unsur bentuk dan makna simbolik yang terkandung pada gerabah peninggalan Majapahit memiliki rangkaian yang terkait dengan budaya dalam kehidupan masyarakat dan merupakan aset yang tak ternilai bagi kehidupan sosial budaya. Kajian ini menggunakan metode kualitatif dengan maksud mengkaji bentuk dan makna simbolik yang terdapat di balik perwujudan figurin gerabah Majapahit. Metode yang digunakan adalah dengan memadukan pendekatan historis dan pendekatan estetik. Sementara teknik penelitian meliputi; teknik pengamatan atau observasi, wawancara, dokumentasi, dan studi literatur untuk memperoleh data yang akurat. Agar memperoleh akurasi, validitas, reliabilitas data yang mendukung pembahasan, maka analisis yang dikembangkan akan ditempuh dengan mengidentifikasi dan mengklasifikasi berbagai informasi tertulis, lisan dan visual. Kemudian dilanjutkan dengan menganalisis data secara tekstual dan kontekstual. 


\section{Bentuk dan Makna Simbolik Figurin Gerabah Majapahit 1350-1389}

\subsection{Bentuk Figurin Laki-laki}

Di Trowulan banyak ditemukan figurin yang menggambarkan sosok laki-laki. Arca figurin laki-laki dapat dikelompokan menjadi tiga yaitu: pendeta, kaum bangsawan dan rakyat biasa. Arca pendeta digambarkan dengan rambut disanggul di atas kepala atau tangan disilangkan di depan dada. Arca bangsawan digambarkan memakai perhiasan lengkap dan pada dahinya terdapat urna. Sedang arca laki-laki dari golongan rakyat biasa digambarkan berambut pendek, bertutup kepala, tidak memakai baju. Teknik pembuatannya langsung memakai jari tangan dan detailnya dibuat dengan teknik gores, cukil dan pres. Fungsinya sebagai benda bekal kubur, arca persembahan dan boneka pertunjukkan yang memerankan tokoh dalam cerita tertentu.
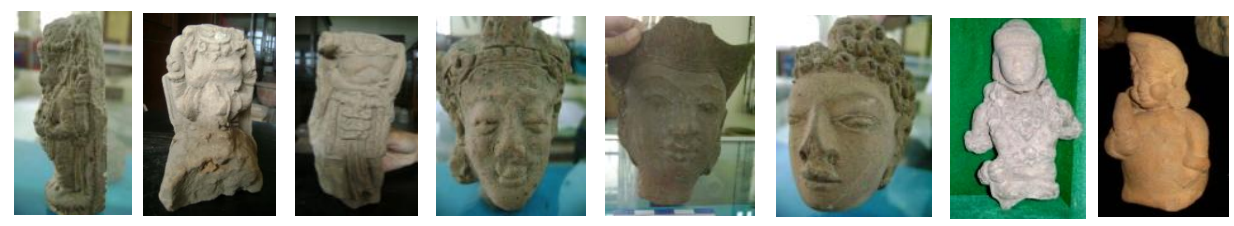

Gambar 1 Beberapa bentuk figurin laki-laki.

\subsubsection{Arca Dewa Siwa}

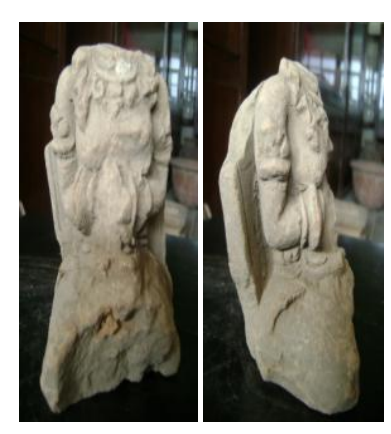

Di India maupun Indonesia, Siwa adalah figur dewa yang paling terkenal. Di Jawa, ia dianggap yang tertinggi, karenanya ada yang menganggapnya sebagai Mahadewa. Tanda-tanda sebagai Siwa ditunjukan pada mahkotanya yang terdapat tengkorak di atas bulan sabit, adanya mata ketiga pada dahi, bertangan 4, berselempangkan ular, mengenakan kulit harimau dipinggang serta senjata trisula pada sandaran. Tangan-tangannya memegang kipas, tasbih, tunas bunga teratai dan benda bulat sebagai benih alam semesta.

Arca digambarkan dalam sikap duduk bersila di atas padmasana. Kedua telapak tangan di atas pangkuan, yang sebagian sudah pecah sehingga tidak diketahui lagi benda yang menjadi laksananya. Arca yang dibuat dari gerabah ini mempunyai sandaran berbentuk sisi sejajar, bentuk puncaknya sudah pecah. Sirascakra dipahat polos, berbentuk bulat telur sampai di belakang bahu. Asananya berupa padmasana ganda berbentuk segi empat polos di bagian 
bawah, sementara lapik bagian atas berhias pola segi enam. Kalung yang dipahatkan di bagian leher arca bersusun 2, berhias pola sulur. Kalung yang kecil kecuali berhias pola sulur juga berhias deretan manik-manik. Tangannya mengenakan dua gelang lengan (kelat bahu) dengan pola sulur, sedangkan gelang tangan berbentuk gelang kana. Gelang kaki berwujud untaian manikmanik. Sampur yang dikenakan hanya tampak pada bagian melingkar di paha dan simpul di kanan-kiri pinggul, ujung sampur mengarah ke atas. Sampur yang dikenakan berbentuk polos dan berlipat-lipat. Selain hiasan-hiasan tersebut terdapat untaian manik-manik menjuntai ke bahu.

\subsubsection{Figurin Dewa Siwa}

Tabel 1 Analisis Estetik dan Makna Simbolik Kalung Dewa Siwa.

\begin{tabular}{|c|c|c|c|}
\hline $\begin{array}{c}\text { Bentuk dan detail } \\
\text { kalung }\end{array}$ & ungsi & Makna Simbolik & Analisis \\
\hline $\begin{array}{l}\text { Kalung bermotif } \\
\text { bunga ceplok dan } \\
\text { kuncup yang } \\
\text { dikombinasikan } \\
\text { dengan motif sulur- } \\
\text { suluran. } \\
\text { Ceplok adalah } \\
\text { ragam hias yang } \\
\text { menstilasi bentuk } \\
\text { dari bunga, daun } \\
\text { yang diatur secara } \\
\text { simetris. }\end{array}$ & $\begin{array}{l}\text { Berfungsi } \\
\text { sebagai asesoris } \\
\text { dan } \\
\text { simbol/tanda. }\end{array}$ & $\begin{array}{l}\text { Motif sulur-suluran } \\
\text { melambangkan } \\
\text { kehidupan yang } \\
\text { mengandung } \\
\text { pengertian suci. } \\
\text { Sulur-suluran juga } \\
\text { merupakan simbol } \\
\text { kesuburan dan } \\
\text { kehidupan yang } \\
\text { bergerak dinamis. } \\
\text { Motif ceplok } \\
\text { merupakan simbol } \\
\text { tentang alam semesta } \\
\text { dan kekuasaan } \\
\text { diantara manusia. } \\
\text { Motif kuncup } \\
\text { merupakan simbol } \\
\text { kematian dan } \\
\text { kehidupan kembali, } \\
\text { kesempurnaan, } \\
\text { kekayaan dan } \\
\text { kemegahan serta } \\
\text { keluhuran budi } \\
\text { pekerti. }\end{array}$ & $\begin{array}{l}\text { Kalung berbentuk lingkaran } \\
\text { karena mengikuti bentuk } \\
\text { leher. Kalung dibuat dalam } \\
\text { dua komponen yaitu rantai } \\
\text { dan gantungannya yang } \\
\text { berbentuk gabungan dari } \\
\text { motif sulur-suluran dan } \\
\text { kuncup bunga. Kombinasi } \\
\text { bentuk sangat harmonis } \\
\text { seimbang kiri dan kanan. } \\
\text { Kalung tergantung tinggi } \\
\text { mengikat dari bagian leher } \\
\text { yang memperlihatkan status } \\
\text { dan simbol keagungan dari } \\
\text { dewa Siwa. Secara visual } \\
\text { bentuk didominasi dengan } \\
\text { elemen sulur-suluran. Hal } \\
\text { ini mempertimbangkan } \\
\text { aspek fungsi sebagai simbol } \\
\text { kehidupan. Bentuk bunga } \\
\text { dan sulur-suluran } \\
\text { merupakan perpaduan } \\
\text { antara rantai dan } \\
\text { gantungannya cukup } \\
\text { dominan sehingga cukup } \\
\text { menonjol dan bentuknya } \\
\text { dapat dikenali. } \\
\text { - Makna Denotatif } \\
\text { Kalung menginformasikan } \\
\text { fungsi guna dan fungsi } \\
\text { simbolis dengan } \\
\text { menggunakan elemen sulur- } \\
\text { suluran, ceplok dan kuncup }\end{array}$ \\
\hline
\end{tabular}




\begin{tabular}{|c|c|c|c|}
\hline $\begin{array}{l}\text { Bentuk dan detail } \\
\text { kalung }\end{array}$ & Fungsi & Makna Simbolik & Analisis \\
\hline & & & $\begin{array}{l}\text { bunga. Motif suluran pada } \\
\text { gantungan kalung } \\
\text { ditempatkan di kiri dan } \\
\text { kanan motif ceplok dan } \\
\text { kuncup bunga secara } \\
\text { simetris. } \\
\text { - Makna Konotatif } \\
\text { Dari bentuk kalung yang } \\
\text { digunakan melambangkan } \\
\text { pemilikinya seorang laki- } \\
\text { laki/dewa. Penggunaan } \\
\text { gantungan kalung berbentuk } \\
\text { sulur-suluran } \\
\text { melambangkan kehidupan } \\
\text { yang mengandung makna } \\
\text { kesempurnaan dan } \\
\text { kesucian, sesuai dengan } \\
\text { dewa Siwa yang dianggap } \\
\text { sebagai Mahadewa yang } \\
\text { memiliki sifat } \\
\text { kebijaksanaan dan } \\
\text { mengayomi. }\end{array}$ \\
\hline
\end{tabular}

Tabel 2 Analisis Estetik dan Makna Kelat Bahu Dewa Siwa.

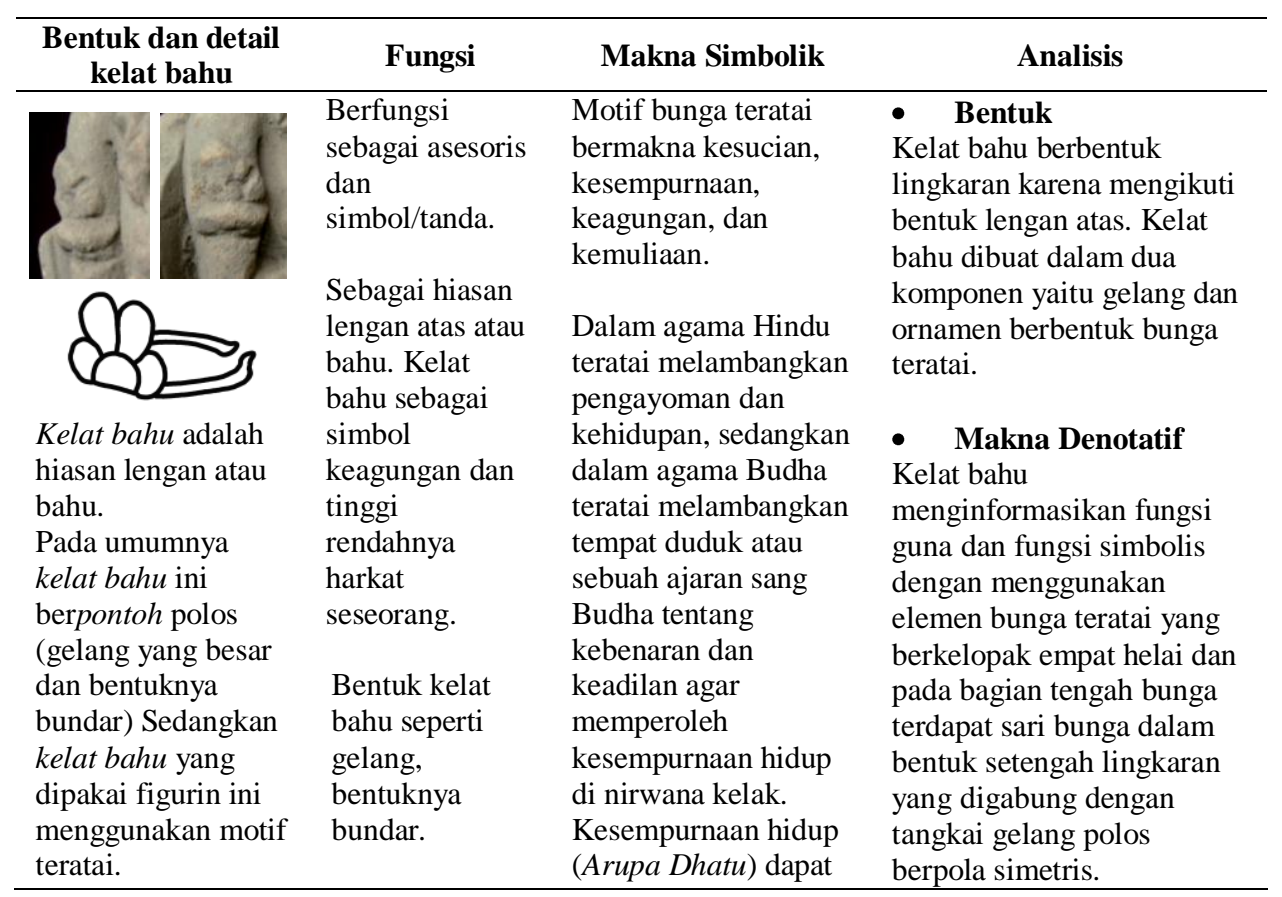




\begin{tabular}{|c|c|c|c|}
\hline $\begin{array}{c}\text { Bentuk dan detail } \\
\text { kelat bahu }\end{array}$ & Fungsi & Makna Simbolik & Analisis \\
\hline & $\begin{array}{l}\text { Mempunyai } \\
\text { ragam hias } \\
\text { motif tumbuh- } \\
\text { tumbuhan } \\
\text { dengan bentuk } \\
\text { bunga teratai. }\end{array}$ & $\begin{array}{l}\text { tercapai apabila } \\
\text { memegang ajaran } \\
\text { bunga teratai yaitu } \\
\text { selalu dapat } \\
\text { mengayomi dan } \\
\text { memberikan ajaran } \\
\text { kebaikan (teratai } \\
\text { putih), berani } \\
\text { membela kebenaran } \\
\text { (teratai merah) dan } \\
\text { setia terhadap dharma } \\
\text { (teratai biru). }\end{array}$ & $\begin{array}{l}\text { - Makna Konotatif } \\
\text { Dari segi bentuk kelat bahu } \\
\text { melambangkan pemiliknya } \\
\text { seorang laki-laki/dewa. } \\
\text { Penggunaan kelat bahu } \\
\text { berbentuk bunga teratai } \\
\text { melambangkan } \\
\text { kewibawaan. Hal ini } \\
\text { merupakan manifestasi dari } \\
\text { Siwa yang selalu } \\
\text { memberikan kedamaian dan } \\
\text { keteduhan pada manusia. }\end{array}$ \\
\hline
\end{tabular}

Tabel 3 Analisis Estetik dan Makna Simbolik Gelang Dewa Siwa.

\begin{tabular}{|c|c|c|c|}
\hline $\begin{array}{c}\text { Bentuk dan detail } \\
\text { Gelang }\end{array}$ & Fungsi & Makna Simbolik & Analisis \\
\hline $\begin{array}{l}\text { Berbentuk } \\
\text { lingkaran ada yang } \\
\text { berukuran besar } \\
\text { dan ada yang kecil. }\end{array}$ & $\begin{array}{l}\text { Berfungsi } \\
\text { sebagai asesoris } \\
\text { dan } \\
\text { simbol/tanda. } \\
\text { Sebagai hiasan } \\
\text { pergelangan } \\
\text { tangan. } \\
\text { Gelang yang } \\
\text { dipakai } \\
\text { merupakan } \\
\text { jenis gelang } \\
\text { kana dan } \\
\text { pontoh. }\end{array}$ & $\begin{array}{l}\text { Lingkaran adalah } \\
\text { permulaan semua } \\
\text { ciptaan Lingkaran } \\
\text { merupakan lambang } \\
\text { keagungan dan } \\
\text { kekuasaan, juga } \\
\text { sebagai simbol } \\
\text { matahari yang } \\
\text { bermakna sumber } \\
\text { segala kehidupan. } \\
\text { Lingkaran merupakan } \\
\text { sistem simbol yang } \\
\text { dapat diterapkan di } \\
\text { berbagai hal. } \\
\text { Bentuk bulat } \\
\text { melambangkan dunia } \\
\text { ini hanya singgahan } \\
\text { saja, segala sesuatu } \\
\text { akan berakhir dan } \\
\text { ditinggalkan, untuk } \\
\text { itu manusia harus } \\
\text { selalu mawas diri dan } \\
\text { mempersiapkan diri } \\
\text { atas segala sesuatu } \\
\text { yang dilakukan dan } \\
\text { harus bisa } \\
\text { dipertanggungjawabk } \\
\text { an. }\end{array}$ & $\begin{array}{l}\text { - Bentuk } \\
\text { Gelang sebagai hiasan yang } \\
\text { melingkar pada pergelangan } \\
\text { tangan berbentuk bulat polos } \\
\text { dengan penambahan ornamen } \\
\text { pada bidang gelang. } \\
\text { - Makna Denotatif } \\
\text { Secara visual gelang } \\
\text { berbentuk dua buah bulatan } \\
\text { polos tanpa motif dengan } \\
\text { bentuk yang seimbang kiri } \\
\text { dan kanan. Gelang berbentuk } \\
\text { bulat berpasangan kecil dan } \\
\text { besar berjumlah dua buah, hal } \\
\text { ini untuk menunjukkan bahwa } \\
\text { kedudukan dewa berbeda } \\
\text { dengan manusia biasa. } \\
\text { - Makna Konotatif } \\
\text { Gelang dengan motif kana } \\
\text { dimaknai sebagai perhiasan } \\
\text { yang memberikan kesan } \\
\text { kesederhanaan. } \\
\text { Sesuai dengan sifat Siwa yang } \\
\text { selalu bersikap Dhyana } \\
\text { Mudra (melindungi), } \\
\text { memiliki sifat kebijaksanaan } \\
\text { yang selalu memancarkan } \\
\text { kasih sayang kepada manusia. }\end{array}$ \\
\hline
\end{tabular}


Tabel 4 Analisis Estetik dan Makna Simbolik Sampur Dewa Siwa.

\begin{tabular}{|c|c|c|c|}
\hline $\begin{array}{c}\text { Bentuk dan detail } \\
\text { Sampur }\end{array}$ & Fungsi & Makna Simbolik & Analisis \\
\hline $\begin{array}{l}\qquad \text { I }_{\text {II }} \\
\text { Sampur yang } \\
\text { dikenakan hanya } \\
\text { tampak pada bagian } \\
\text { melingkar di paha } \\
\text { dan simpul di } \\
\text { kanan-kiri pinggul, } \\
\text { ujung sampur } \\
\text { mengarah ke atas. } \\
\text { Sampur yang } \\
\text { dikenakan } \\
\text { berbentuk polos } \\
\text { dan berlipat-lipat } \\
\text { dilengkapi untaian } \\
\text { manik-manik } \\
\text { berbentuk piramida } \\
\text { terpenggal. }\end{array}$ & $\begin{array}{l}\text { Berfungsi } \\
\text { sebagai } \\
\text { selendang yang } \\
\text { digantungkan di } \\
\text { sekitar pinggang } \\
\text { atau pinggul, } \\
\text { dengan kedua } \\
\text { ujung terurai } \\
\text { lepas. } \\
\text { Terkadang ada } \\
\text { bagian yang } \\
\text { digantungkan } \\
\text { melengkung } \\
\text { pada bagian } \\
\text { depan kaki. } \\
\text { Manik-manik } \\
\text { adalah benda } \\
\text { yang relatif kecil } \\
\text { dan berlubang } \\
\text { ditengahnya } \\
\text { sebagai tempat } \\
\text { untuk dimasuki } \\
\text { sejenis } \\
\text { benang/tali untuk } \\
\text { dirangkai } \\
\text { sebagai untaian. } \\
\text { Manik-manik } \\
\text { dalam } \\
\text { masyarakat Jawa } \\
\text { berfungsi } \\
\text { sebagai hiasan } \\
\text { dan sarana } \\
\text { upacara } \\
\text { keagamaan }\end{array}$ & $\begin{array}{l}\text { Manik-manik } \\
\text { berbentuk piramida } \\
\text { terpenggal memiliki } \\
\text { makna harmoni yaitu } \\
\text { kehidupan atas. } \\
\text { Bentuk gunung atau } \\
\text { segitiga menegaskan } \\
\text { bentuk yang } \\
\text { berstruktur segitiga } \\
\text { artinya pola tiga, } \\
\text { dimana bagian atas } \\
\text { adalah yang paling } \\
\text { sempurna. } \\
\text { Gambaran akan } \\
\text { kosmologi tercermin } \\
\text { dengan jelas, bahwa } \\
\text { untuk mencapai dunia } \\
\text { atas manusia harus } \\
\text { melalui perantara } \\
\text { yang mampu } \\
\text { menghubungkan } \\
\text { antara dunia atas dan } \\
\text { bawah. } \\
\text { Komposisi memiliki } \\
\text { makna yang senilai } \\
\text { dengan gambaran } \\
\text { dunia atas yang suci } \\
\text { dimana para dewa } \\
\text { bertempat tinggal, } \\
\text { yang merupakan } \\
\text { harapan dan tujuan. }\end{array}$ & $\begin{array}{l}\text { Makna Denotatif } \\
\text { Sampur menginformasikan } \\
\text { fungsi guna dan fungsi } \\
\text { simbolis dengan } \\
\text { menggunakkan elemen } \\
\text { piramida terpenggal berupa } \\
\text { rumbai yang terdiri dari } \\
\text { beberapa buah, sedangkan } \\
\text { ikatan kain yang terletak pada } \\
\text { selendang terdiri dari motif } \\
\text { bunga yang mempunyai } \\
\text { kelopak beberapa helai } \\
\text { dengan sari bunga yang } \\
\text { membentuk setengah } \\
\text { lingkaran. Bentuk seimbang } \\
\text { kiri dan kanan, melingkar } \\
\text { pada bagian pinggul dengan } \\
\text { dihiasi manik-manik. } \\
\text { Sampur yang dipakai laki-laki } \\
\text { berbeda fungsinya dengan } \\
\text { wanita, untuk laki-laki } \\
\text { sampur dipakai hanya sebagai } \\
\text { pelengkap/hiasan saja. } \\
\text { Makna Konotatif } \\
\text { Sampur memperlihatkan } \\
\text { bahwa dari segi bentuk yang } \\
\text { digunakan melambangkan } \\
\text { seorang laki-laki/dewa. } \\
\text { Penggunaan sampur bermotif } \\
\text { piramida terpenggal } \\
\text { melambangkan sesuatu yang } \\
\text { transenden yang mampu } \\
\text { menghubungkan antara dunia } \\
\text { atas dan bawah. }\end{array}$ \\
\hline
\end{tabular}


Tabel 5 Analisis Estetik dan Makna Simbolik Ptrabha Dewa Siwa.

\begin{tabular}{|c|c|c|c|}
\hline $\begin{array}{c}\text { Bentuk dan detail } \\
\text { Prabha }\end{array}$ & Fungsi & Makna Simbolik & Analisis \\
\hline 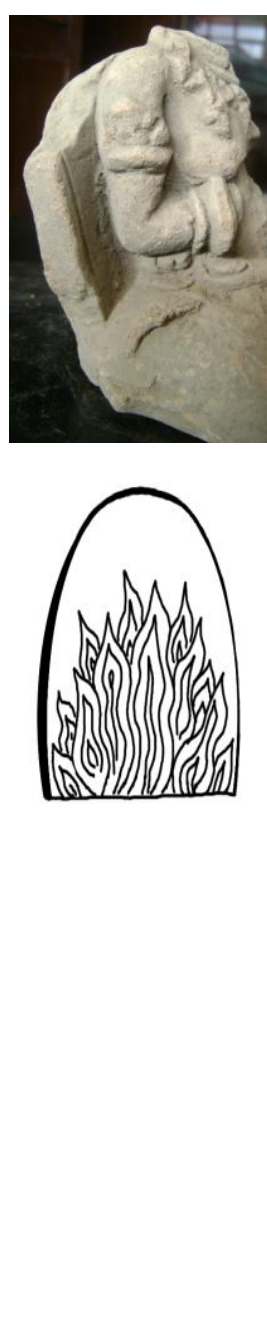 & $\begin{array}{l}\text { Berfungsi } \\
\text { sebagai tempat } \\
\text { duduk sang } \\
\text { dewa }\end{array}$ & $\begin{array}{l}\text { Teratai adalah salah } \\
\text { satu simbolisasi } \\
\text { penting yang muncul } \\
\text { pada kebudayaan } \\
\text { Hindu-Budha. Teratai } \\
\text { dipercaya sebagai } \\
\text { simbolisasi dari } \\
\text { pertumbuhan, } \\
\text { penciptaan, lambang } \\
\text { keindahan dharma } \\
\text { dan ketidakkekalan } \\
\text { dari segala sesuatu } \\
\text { yang ada di dunia ini. } \\
\text { Teratai merupakan } \\
\text { ajaran sang Budha } \\
\text { tentang kebenaran dan } \\
\text { keadilan agar } \\
\text { memperoleh } \\
\text { kesempurnaan hidup } \\
\text { di nirwana kelak. } \\
\text { Teratai } \\
\text { melambangkan } \\
\text { kesucian dan } \\
\text { kesempurnaan, } \\
\text { dimana bunga ini } \\
\text { tetap bisa tumbuh } \\
\text { dengan indah dan } \\
\text { bersih walaupun } \\
\text { akarnya berada di } \\
\text { dalam lumpur. } \\
\text { Motif api adalah } \\
\text { benda alam yang } \\
\text { dipandang suci dan } \\
\text { sebagai sumber hidup. }\end{array}$ & 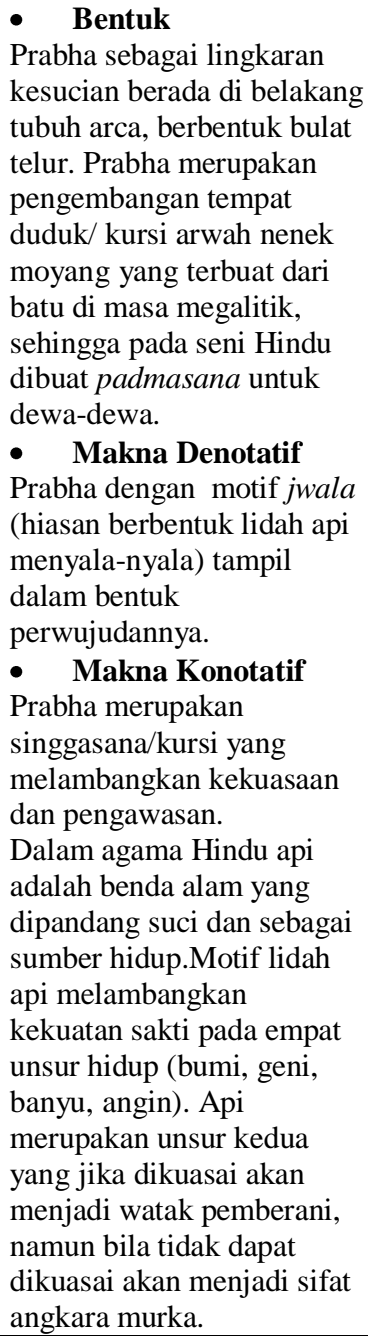 \\
\hline
\end{tabular}

\subsection{Bentuk Figurin Wanita}

Figurin gerabah wanita yang terdapat di Trowulan terdiri dari berbagai posisi, di antaranya dengan posisi berdiri maupun duduk. Ada juga beberapa bentuk figurin yang sedang memainkan alat-alat musik, di antaranya sedang memetik wina, menabuh rebana, dan lain-lain. Bentuk model rambut bermacam-macam, ada yang disanggul dan ada juga yang disisir ke belakang. Serta memakai asesoris berupa gelang, kalung dan subang serta hiasan bunga di atas telinganya. 
Tubuhnya memakai kain, kemben serta selendang yang diselempangkan diatas pundaknya. Arca-arca ini menggambarkan penampilan atau status wanita pada masa Majapahit. Teknik pembuatannya langsung memakai jari tangan dan detailnya dibuat dengan teknik gores, cukil dan pres. Fungsinya sebagai bekal kubur, hiasan atau memerankan tokoh dalam cerita tertentu.
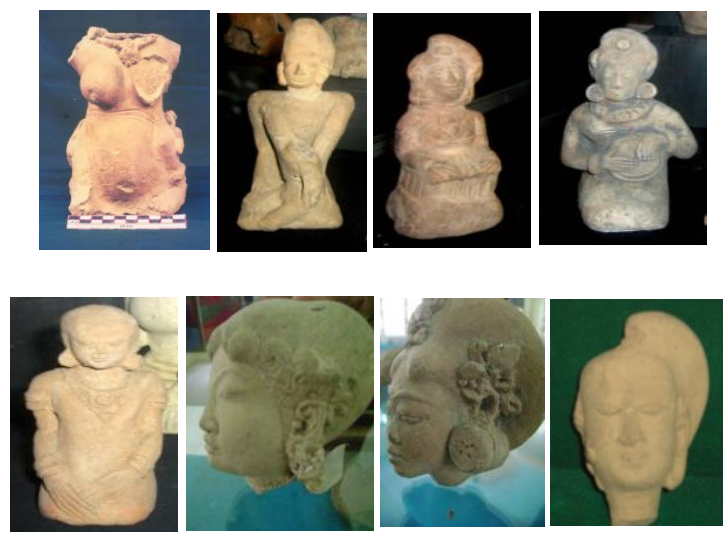

Gambar 2 Beberapa bentuk figurin wanita.

\subsubsection{Arca Dewi Hariti}
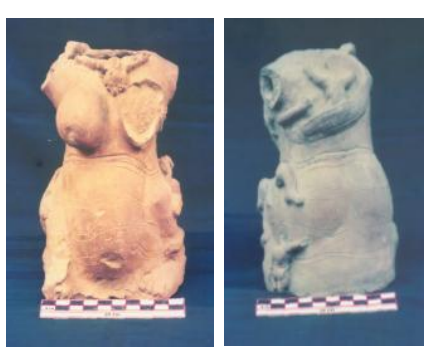

Di dalam agama Hindu, Hariti dikenal sebagai 'Dewi Pelindung Anak', sedangkan dalam agama Budha Hariti merupakan 'Lambang Kesuburan'. Di dalam agama Budha, Hariti adalah seorang yaksha perempuan atau yakshini yang aslinya berasal dari kota Rajagriha. Yaksha adalah salah satu dari delapan jenis makhluk gaib yang diceritakan memuja dan melindungi Dharma.

Yaksha adalah sejenis iblis pemakan daging atau roh yang menyusun pasukan raja penjaga Vaishravana. Sebagai 'Pelindung Anak' dan wanita yang melahirkan, Hariti juga sebagai pelindung Dharma dan gambaran penuh welas asihnya sebagai 'Pemberi Anak' kadang menyebabkan ia disalahkenali dengan Bodhisattva Avalokitesvara.

Di dalam agama Hindu dan Budha, Hariti termasuk dewi pujaan dan keberadaannya sangat diperlukan. Hariti dianggap sebagai tokoh baik dan jahat. Sebagai tokoh baik ia dipuja oleh pemeluknya dan dipercaya sebagai dewi penjaga dan pelindung anak-anak oleh orang tua yang sedang kehilangan juga dianggap sebagai ibu para dewi dan identik dengan Wrddhi isteri Kuwera (dewa kekayaan dan penjaga mata angin utara). Sebagai tokoh jahat Hariti disebut 
Jara musuh Kresna. Hariti juga identik dengan Nanda salah satu bentuk Parwati yang diwujudkan mempunyai tangan empat atau delapan.

Arca Hariti di Trowulan menunjukkan adanya kepercayaan masyarakat terhadap tokoh tersebut sebagai dewi pujaan. Dalam pengarcaannya Dewi Hariti digambarkan dikelilingi anak-anak kecil yang mengerubutinya, sebagai ciri pelindung, penyayang, dan sebagai perlambang kesuburan dan kemakmuran juga sebagai dewi pemberi kekayaan.

\subsubsection{Figurin Dewi Hariti}

Tabel 6 Analisis Estetik dan Maktna Simbolik Kalung Dewi Hariti.

\begin{tabular}{|c|c|c|c|}
\hline $\begin{array}{r}\text { Bentuk dar } \\
\text { kalun }\end{array}$ & Fungsi & Makna Simbolik & Analisis \\
\hline $\begin{array}{l}\text { Kalung yang } \\
\text { dipakai merupakan } \\
\text { hiasan yang } \\
\text { tergantung di leher } \\
\text { yang berhias } \\
\text { kombinasi motif } \\
\text { bunga dan sulur- } \\
\text { suluran. }\end{array}$ & $\begin{array}{l}\text { Merupakan } \\
\text { hiasan yang } \\
\text { tergantung pada } \\
\text { leher. Kalung } \\
\text { ini } \\
\text { melambangkan } \\
\text { tinggi } \\
\text { rendahnya } \\
\text { harkat } \\
\text { seseorang baik } \\
\text { pada tokoh raja } \\
\text { maupun dewa. } \\
\text { Berfungsi } \\
\text { kalung sebagai } \\
\text { perlengkapan/ } \\
\text { hiasan } \\
\text { berbusana } \\
\text { sehingga } \\
\text { tampak } \\
\text { kemegahan. } \\
\text { Menambah nilai } \\
\text { indah, serasi } \\
\text { dan harmonis } \\
\text { dalam } \\
\text { berbusana. } \\
\text { Bentuk yang } \\
\text { rumit } \\
\text { mengungkapkan } \\
\text { keindahan yang } \\
\text { abadi. }\end{array}$ & $\begin{array}{l}\text { Motif bunga dan sulur } \\
\text { memberi makna suatu } \\
\text { gerak atau siklus } \\
\text { dalam kehidupan dan } \\
\text { keluhuran budi } \\
\text { pekerti.. } \\
\text { Kuncup bunga yang } \\
\text { dipakai sebagai hiasan } \\
\text { kepala kalung } \\
\text { bermakna kesucian, } \\
\text { menjaga kehormatan. } \\
\\
\text { Sulur-suluran dalam } \\
\text { kosmologi Hindu- } \\
\text { Budha merupakan } \\
\text { lambang kehidupan } \\
\text { dan simbol } \\
\text { keseimbangan, } \\
\text { mengandung makna } \\
\text { bahwa untuk } \\
\text { memasuki dunia atas } \\
\text { harus melalui atau } \\
\text { memiliki kesucian } \\
\text { dan kesempurnaan. } \\
\text { Motif pucuk daun } \\
\text { yang melengkung dan } \\
\text { berputar adalah } \\
\text { simbol kesabaran, } \\
\text { selalu tunduk, taat dan } \\
\text { merendahkan diri. }\end{array}$ & $\begin{array}{l}\text { - Bentuk } \\
\text { Kalung berbentuk } \\
\text { lingkaran, dibuat dalam dua } \\
\text { komponen yaitu rantai dan } \\
\text { gantungannya yang } \\
\text { berbentuk oval gabungan } \\
\text { dari motif sulur-suluran dan } \\
\text { kuncup bunga. Kalung } \\
\text { memperlihatkan status dan } \\
\text { simbol keagungan dari dewi } \\
\text { Hariti. } \\
\text { • Makna Denotatif } \\
\text { Kalung menginformasikan } \\
\text { fungsi guna dan fungsi } \\
\text { simbolis. Pada bagian atas } \\
\text { kalung bermotif bunga } \\
\text { berukuran kecil merupakan } \\
\text { kepala kalung yang } \\
\text { menempel pada tali yang } \\
\text { menyerupai rantai kalung. } \\
\text { Pada bagian bawah kepala } \\
\text { kalung terdapat gantungan } \\
\text { kalung berbentuk oval } \\
\text { bermotif bunga yang } \\
\text { berukuran besar yang } \\
\text { dikombinasikan dengan } \\
\text { elemen yang bermotif } \\
\text { sulur-suluran membuat } \\
\text { lengkungan dalam alur yang } \\
\text { estetis. } \\
\text { • Makna Konotatif } \\
\text { Kalung yang digunakan } \\
\text { melambangkan pemiliknya } \\
\text { seorang wanita/dewi. } \\
\text { Penggunaan gantungan }\end{array}$ \\
\hline
\end{tabular}




\begin{tabular}{|c|c|c|c|}
\hline $\begin{array}{c}\text { Bentuk dan detail } \\
\text { kalung }\end{array}$ & Fungsi & Makna Simbolik & Analisis \\
\hline & & & $\begin{array}{l}\text { kalung berbentuk sulur- } \\
\text { suluran melambangkan } \\
\text { kesuburan, seperti yang } \\
\text { dipercaya oleh masyarakat } \\
\text { bahwa Dewi Hariti dapat } \\
\text { membawa anugerah } \\
\text { kesuburan dan kemakmuran } \\
\text { juga dipercaya sebagai } \\
\text { Dewi pemberi kekayaan. } \\
\text { Sedangkan motif kuncup } \\
\text { bunga melambangkan } \\
\text { ketaatan, seperti halnya } \\
\text { Dewi Hariti menjadi } \\
\text { penganut agama Budha } \\
\text { yang taat dan penuh kasih } \\
\text { sayang yang dapat dijadikan } \\
\text { keteladanan. }\end{array}$ \\
\hline
\end{tabular}

Tabel 7 Analisis Estetik dan Makna Simbolik Kain Panjang Dewi Hariti.

\begin{tabular}{|c|c|c|c|}
\hline $\begin{array}{c}\text { Bentuk dan detail } \\
\text { Kain Panjang }\end{array}$ & Fungsi & Makna Simbolik & Analisis \\
\hline 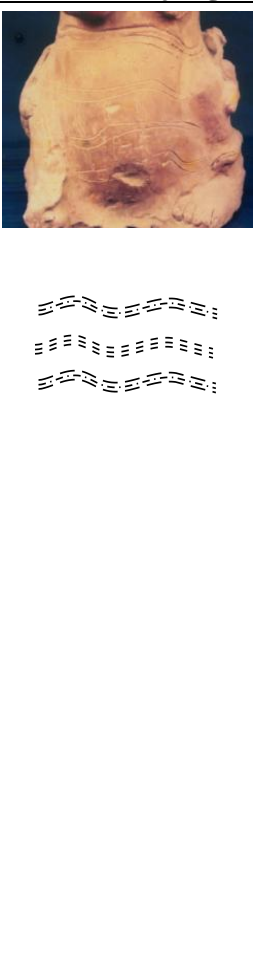 & $\begin{array}{l}\text { Sebagai busana } \\
\text { yang dipakai } \\
\text { untuk bebed } \\
\text { atau sarung } \\
\text { Kain yang } \\
\text { dikenakan } \\
\text { berhias pola } \\
\text { geometris, } \\
\text { panjangnya } \\
\text { sampai di atas } \\
\text { pergelangan } \\
\text { kaki tetapi } \\
\text { bagian } \\
\text { bawahnya } \\
\text { berlekuk. }\end{array}$ & $\begin{array}{l}\text { Garis lengkung } \\
\text { identik dengan bentuk } \\
\text { geometris. Dalam } \\
\text { kosmologi Hindu- } \\
\text { Budha bermakna } \\
\text { penghubung antara } \\
\text { dunia atas dan dunia } \\
\text { bawah. Tangga juga } \\
\text { bermakna jalan } \\
\text { menuju tempat di atas } \\
\text { atau penghubung } \\
\text { dunia bawah dan atas } \\
\text { yang bermakna suci. }\end{array}$ & $\begin{array}{l}\text { - Bentuk } \\
\text { Kain melilit tubuh bagian } \\
\text { bawah (panggul sampai mata } \\
\text { kaki) dengan ketat sehingga } \\
\text { garis yang terlihat berupa garis- } \\
\text { garis yang luwes membentuk } \\
\text { siluet tubuh, hal ini terutama } \\
\text { terfokus pada bagian panggul. } \\
\text { • Makna Denotatif } \\
\text { Kain panjang yang digunakan } \\
\text { menampilkan elemen garis } \\
\text { sehingga menonjolkan bentuk } \\
\text { tubuh. Kain panjang berlipat } \\
\text { bergelombang tanpa wiron. } \\
\text { Motif garis yang kecil dan halus } \\
\text { memberikan kesan padat dan } \\
\text { ramping sehingga memberi } \\
\text { kesan luwes dan anggun } \\
\text { • Makna Konotatif } \\
\text { Motif garis yang halus } \\
\text { melambangkan kelembutan } \\
\text { yang bermakna memberi rasa } \\
\text { aman dan dapat memberi } \\
\text { ketenangan seperti sifat Dewi } \\
\text { Hariti yang selalu memberi rasa } \\
\text { aman pada anak-anak } \\
\text { disekelilingnya. Oleh karenanya }\end{array}$ \\
\hline
\end{tabular}


Hariti dianggap sebagai 'Dewi Ibu' atau Dewi pelindung anakanak yang penyayang dan penuh cinta. Hariti sebagai simbol wanita mempunyai seluruh syarat terbaik sebagai seorang wanita, isteri dan seorang ibu.

\subsection{Bentuk Figurin Anak-anak}

Figurin anak-anak adalah arca dengan roman muka yang pada umumnya menggambarkan wajah kekanak-kanakan, berpipi tembem, bibir kecil, mata besar, serta berhidung kecil. Teknik pembuatannya langsung memakai jari tangan dan detailnya dibuat dengan teknik gores, cukil dan pres. Fungsinya diduga digunakan sebagai boneka mainan dan boneka pertunjukkan dalam lakon tertentu. Dari empat buah arca anak-anak hanya satu buah saja yang dilengkapi dengan badan, itupun karena hasil penyambungan dibagian leher. Melihat proporsinya nampak bahwa figurin tidak mempunyai perbandingan yang seimbang antara besarnya kepala dengan badan; bagian kepala pada arca tersebut nampak terlalu besar untuk ukuran kepala seorang anak.
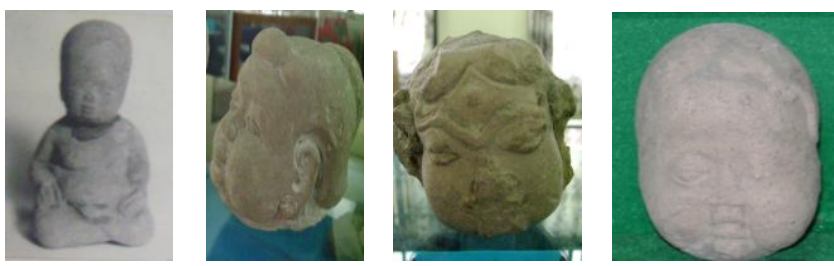

Gambar 3 Beberapa bentuk figurin anak laki-laki.

\subsubsection{Figurin Anak laki-laki}

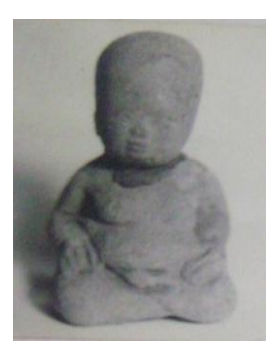

Dari empat buah figurin anak-anak hanya sebuah saja yang dilengkapi dengan badan, itupun karena hasil penyambungan di bagian leher. Melihat proporsinya nampak bahwa arca ini mempunyai perbandingan yang tidak seimbang antara ukuran kepala dan badannya. Kalau dilihat bagian badannya saja, ada kemungkinan bahwa badan tersebut menggambarkan tubuh seorang anak yang berbadan gemuk. Ciri tubuh seorang anak nampak pada bagian bahunya yang belum berkembang dan ukuran tangannya yang pendek kegemuk-kegemukan yang lazim dimiliki oleh seorang anak, akan tetapi sikap duduk dan posisi tangannya sangat meragukan anggapan kalau yang digambarkan dengan cara demikian adalah seorang anak. Dengan tidak 
seimbangnya proporsi serta sikap duduk yang tidak cocok bagi seorang anak, maka kemungkinan ada kesalahan rekonstruksi dimana kepala arca dipasang pada badan yang bukan miliknya.

Berdasarkan tatanan rambutnya, figurin gerabah anak-anak dapat dikelompokkan dalam dua bagian, yaitu: model rambut kuncung dan rambut kucir. Rambut yang digambarkan pada figurin ini merupakan jenis rambut kuncung. Jenis model rambut ini merupakan cara memotong rambut yang sampai sekarang masih dilakukan di dalam masyarakat Jawa dan Bali. Di Jawa seorang anak yang telah berumur 210 hari dicukur rambutnya sampai licin, kecuali segumpal rambut di bagian depan agar supaya anak terhindar dari penyakit. Sedangkan rambut kucir selain ditampilkan pada figurin anak-anak juga dibuat pada figurin dalam bentuk orang dewasa, seperti tokoh Panakawan misalnya Semar, Gareng dan Petruk. Kemungkinan pemberian kucir pada para Panakawan adalah untuk memberi kesan atas tingkah laku mereka yang lucu dan kadang ke kanak-kanakan.

Ditinjau dari segi pembuatan nampak bahwa figurin ini diselesaikan dengan penggarapan yang teliti. Figurin ini berukuran kecil dan bentuknya sederhana tetapi memancarkan kekuatan ekspresi. Seniman Majapahit ternyata telah menemukan cara yang baik untuk menggambarkan raut wajah anak-anak. Garisgaris wajah yang serba lembut dan ukuran dahi yang cenderung lebar serta bentuk mata yang bulat memberi kesan yang kuat tentang karakter anatomi anak-anak.

\subsubsection{Figurin Anak Laki-Laki}

Tabel 8 Analisis Estetik dan Makna Simbolik Rambut Kuncung Anak LakiLaki.

\begin{tabular}{|c|c|c|c|}
\hline $\begin{array}{l}\text { Bentuk dan detail } \\
\text { Rambut Kuncung }\end{array}$ & Fungsi & Makna Simbolik & Analisis \\
\hline & $\begin{array}{l}\text { Rambut yang } \\
\text { ditampilkan } \\
\text { pada figurin ini } \\
\text { merupakan jenis } \\
\text { rambut } \\
\text { kuncung. } \\
\text { Jenis model } \\
\text { rambut ini } \\
\text { merupakan } \\
\text { rambut yang } \\
\text { sampai sekarang } \\
\text { masih dilakukan } \\
\text { di dalam } \\
\text { masyarakat }\end{array}$ & & $\begin{array}{l}\text { - Bentuk } \\
\text { Segumpal rambut di bagian } \\
\text { depan. } \\
\text { - Makna Denotatif } \\
\text { Tatanan rambut kuncung } \\
\text { merupakan tatanan rambut } \\
\text { yang biasa terdapat pada } \\
\text { anak-anak di Jawa. Selain } \\
\text { tatanan rambut, tidak ada } \\
\text { lagi hiasan atau atribut lain } \\
\text { yang dikenakan oleh anak } \\
\text { dalam figurin gerabah ini. } \\
\text { - Makna Konotatif } \\
\text { Bentuk dan tatanan rambut } \\
\text { merupakan figurin yang }\end{array}$ \\
\hline
\end{tabular}




\begin{tabular}{ll}
\hline Jawa dan Bali, & digolongkan dalam \\
dimana seorang & masyarakat biasa. Dari \\
anak yang telah & figurin anak dengan tatanan \\
berumur 210 & rambut kuncung ini hanya \\
hari dicukur & terdapat kepercayaan dari \\
sampai licin. & orang Jawa bahwa tatanan \\
& rambut kuncung merupakan \\
& kepercayaan agar anak \\
& terhindar dari penyakit. \\
\hline
\end{tabular}

Tabel 9 Analisis Estetik dan Makna Simbolik duduk bersila Anak Laki-Laki.

\begin{tabular}{|c|c|c|c|}
\hline $\begin{array}{l}\text { Bentuk dan detail } \\
\text { duduk bersila }\end{array}$ & Fungsi & Makna Simbolik & Analisis \\
\hline & $\begin{array}{l}\text { Sikap duduk } \\
\text { bersila } \\
\text { menandakan } \\
\text { bahwa pada } \\
\text { masa itu budaya } \\
\text { duduk di atas } \\
\text { kursi belum } \\
\text { dikenal, apalagi } \\
\text { bagi masyarakat } \\
\text { biasa yang biasa } \\
\text { duduk di lantai } \\
\text { dengan bersila. }\end{array}$ & - & $\begin{array}{l}\text { - Bentuk } \\
\text { Sikap duduk bersila merupakan } \\
\text { sikap duduk yang biasa } \\
\text { ditampilkan oleh orang Jawa pada } \\
\text { masa lalu. } \\
\text { - Makna Denotatif } \\
\text { Duduk bersila yang ditampilkan } \\
\text { figurin anak merupakan } \\
\text { kebiasaan masyarakat pada masa } \\
\text { lalu. Hal ini dikarenakan pada } \\
\text { masa itu belum dikenal adanya } \\
\text { budaya duduk di kursi, kecuali } \\
\text { bagi raja pada zaman Majapahit } \\
\text { (dampar kencana). } \\
\text { - Makna konotatif (-) }\end{array}$ \\
\hline
\end{tabular}

\subsection{Bentuk Figurin dengan Wajah Deformasi}

Arca figurin dengan wajah dideformasi ialah figurin yang wajahnya dibuat lebih buruk dari wajah/roman muka pada umumnya, misalnya berwajah mirip kera, bibir tebal, mata sipit serta hidung pesek. Karakter wajah seperti ini antara lain dijumpai pada relief cerita Bubuksah dan Gagangaking di candi Surowono serta relief cerita Panji di Gunung Penanggungan. Teknik pembuatannya langsung memakai jari tangan dan detailnya dibuat dengan teknik gores, cukil dan pres. Fungsinya diduga untuk menggambarkan tokoh yang berwajah lucu dan berwajah kera dalam cerita Ramayana.

Bentuk figurin dengan wajah di deformasipun ada yang dibuat dengan wajah $3 / 4$ pandangan seperti pada figur Semar ini, selain untuk menunjukkan adanya dimensi, juga diperlukan untuk menjalin hubungan dengan tokoh lain. Hal ini biasanya diperuntukkan bagi figurin sebagai boneka pertunjukkan. 

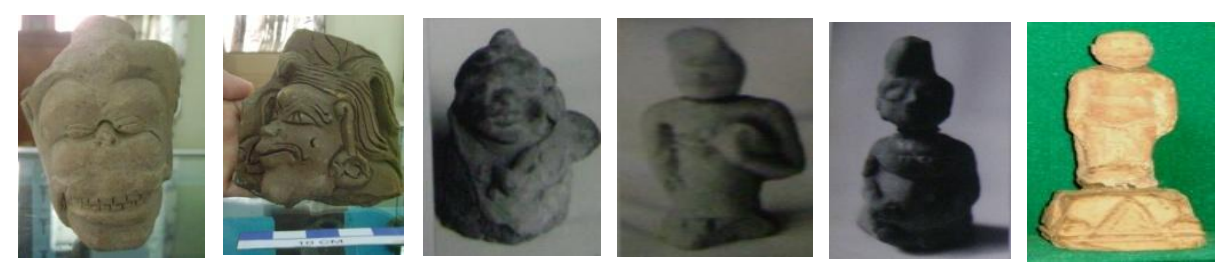

Gambar 4 Beberapa bentuk figurin dengan wajah deformasi.

\subsubsection{Semar}
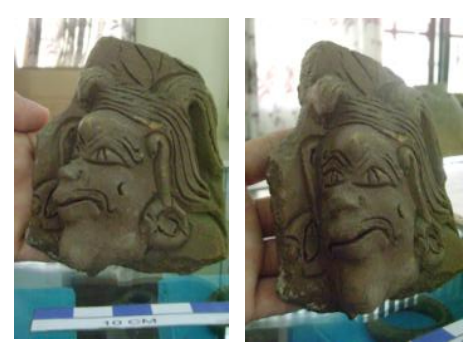

Di kalangan spiritual Jawa, tokoh wayang Semar ternyata dipandang bukan sebagai fakta historis, tetapi lebih bersifat mitologi dan simbolis yaitu: suatu lambang dari pengejawantahan ekspresi, persepsi dan pengertian yang menunjukkan pada konsepsi spiritual. Golongan panakawan tidak memiliki potongan tubuh yang dapat mewakili kelompoknya. Pada golongan ini masing-masing tokoh memiliki kekhasan. Semar bertubuh pendek khas, perut gendut dan pantat mencuat. Mata 'mulan' (ke atas), hidung pesek, mulut besar dan gigi hanya satu, wajah berwarna putih dan tubuh hitam.

Ciri sosok Semar adalah: (a) Berbadan bulat; (b) Bermata sipit kecil; (c) Dagu atau mulutnya diikat pakai rantai sampai ke kaki (d) Tangan kiri kelima jarinya digenggam; (e) Mempunyai satu gigi (f) Memakai kuncung (rambut di kepala) seperti kanak kanak; (g) Tertawannya selalu diakhiri nada tangisan; (h) Berprofil berdiri sekaligus jongkok; (i) Tak pernah menyuruh namun memberikan konsekwensi atas nasehatnya.

Semar dianggap sama dengan akal budi, Ratu Adil, tidak ingin memegang nafsu kekuasaan duniawi. Pada dasarnya menurut mitos kesaktian Semar ini hampir tidak terbatas.Di dalam cerita pewayangan, Semar adalah putra Sang Hyang Wisesa, ia diberi anugerah mustika manik astagina, yang mempunyai 8 daya, yaitu: (a) tidak pernah lapar; (b) tidak pernah mengantuk; (c) tidak pernah jatuh cinta; (d) tidak pernah bersedih; (e) tidak pernah merasa capek; (f) tidak pernah menderita sakit; (g) tidak pernah kepanasan; (h) tidak pernah kedinginan. Kedelapan daya tersebut diikat pada rambut yang ada di ubun-ubun atau kuncung. Dapat dikatakan bahwa Semar merupakan rahmat yang tersembunyi. Siapa pun juga yang diikutinya, hidupnya akan mencapai puncak kesuksesan yang membawa kebahagian abadi lahir batin. 


\subsubsection{Figurin Semar}

Tabel 10 Analisis Estetik dan Makna Simbolik Ikat Rambut.
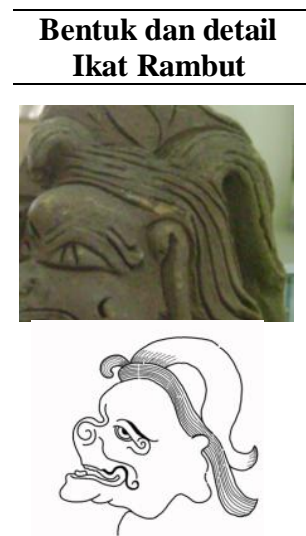

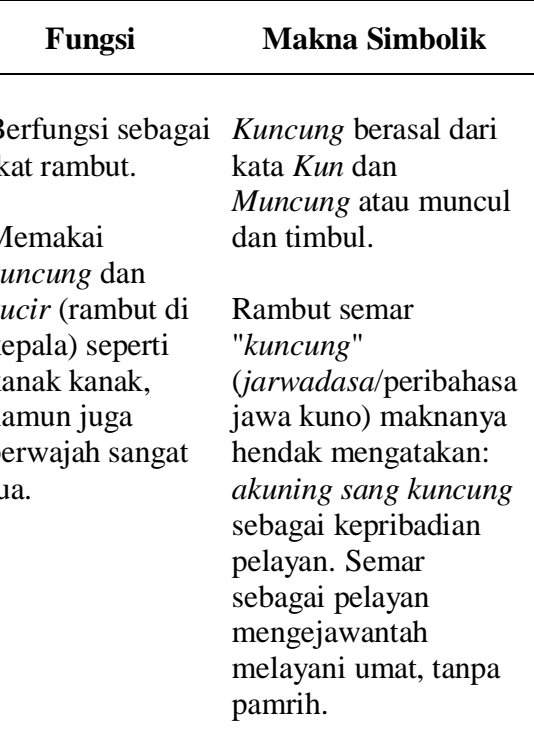

Analisis Estetik

\section{- Bentuk}

Rambut diatur dalam jalinan tunggal sehingga membentuk semacam kucir di bagian tengah atas kepala, bagian atas kucir diberi hiasan yang mungkin berfungsi sebagai pengikat rambut.

\section{- Makna Denotatif}

Pemberian kucir pada

Semar adalah untuk memberi kesan atas tingkah lakunya yang kadangkadang kekanak-kanakan dan jenaka.

\section{- Makna Konotatif}

Ikatan rambut berbentuk 'kucir' mengandung makna penyatuan sifat keduniawian Semar dengan daya-daya transenden. Ikatan rambut yang terdiri dari '8 sakti' atau delapan daya terdapat pada rambut yang diikat dan ada di ubun-ubun.

Tabel 11 Analisis Estetik dan Makna Anting Semar.

\begin{tabular}{|c|c|c|c|}
\hline $\begin{array}{c}\text { Bentuk dan detail } \\
\text { Anting }\end{array}$ & Fungsi & Makna Simbolik & Analisis Estetik \\
\hline & $\begin{array}{l}\text { Sebagai hiasan } \\
\text { daun telinga. } \\
\text { Berbentuk } \\
\text { silinder dan } \\
\text { berukuran } \\
\text { besar. } \\
\text { Pada subang } \\
\text { tersebut } \\
\text { nampak dengan } \\
\text { jelas adanya } \\
\text { lubang di } \\
\text { tengah. }\end{array}$ & $\begin{array}{l}\text { Lingkaran merupakan } \\
\text { lambang kesempurnaan, } \\
\text { keagungan dan } \\
\text { kekuasaan juga sebagai } \\
\text { simbol matahari dan } \\
\text { bulan yang bermakna } \\
\text { sumber segala } \\
\text { kehidupan, lambang } \\
\text { cakra/mata angin dan } \\
\text { simbol kepercayaan } \\
\text { kosmogoni. } \\
\text { Matahari dan bulan juga } \\
\text { merupakan simbol }\end{array}$ & $\begin{array}{l}\text { - Bentuk } \\
\text { Hiasan telinga berbentuk } \\
\text { silinder membentuk bulatan } \\
\text { polos. } \\
\text { - Makna Denotatif } \\
\text { Secara umum anting-anting } \\
\text { polos yang dipakai Semar } \\
\text { mempunyai fungsi guna dan } \\
\text { fungsi simbolis dengan } \\
\text { menggunakan elemen } \\
\text { berbentuk lingkaran dan } \\
\text { dilengkapi motif yang } \\
\text { berbentuk geometris. } \\
\text { - Makna Konotatif }\end{array}$ \\
\hline
\end{tabular}




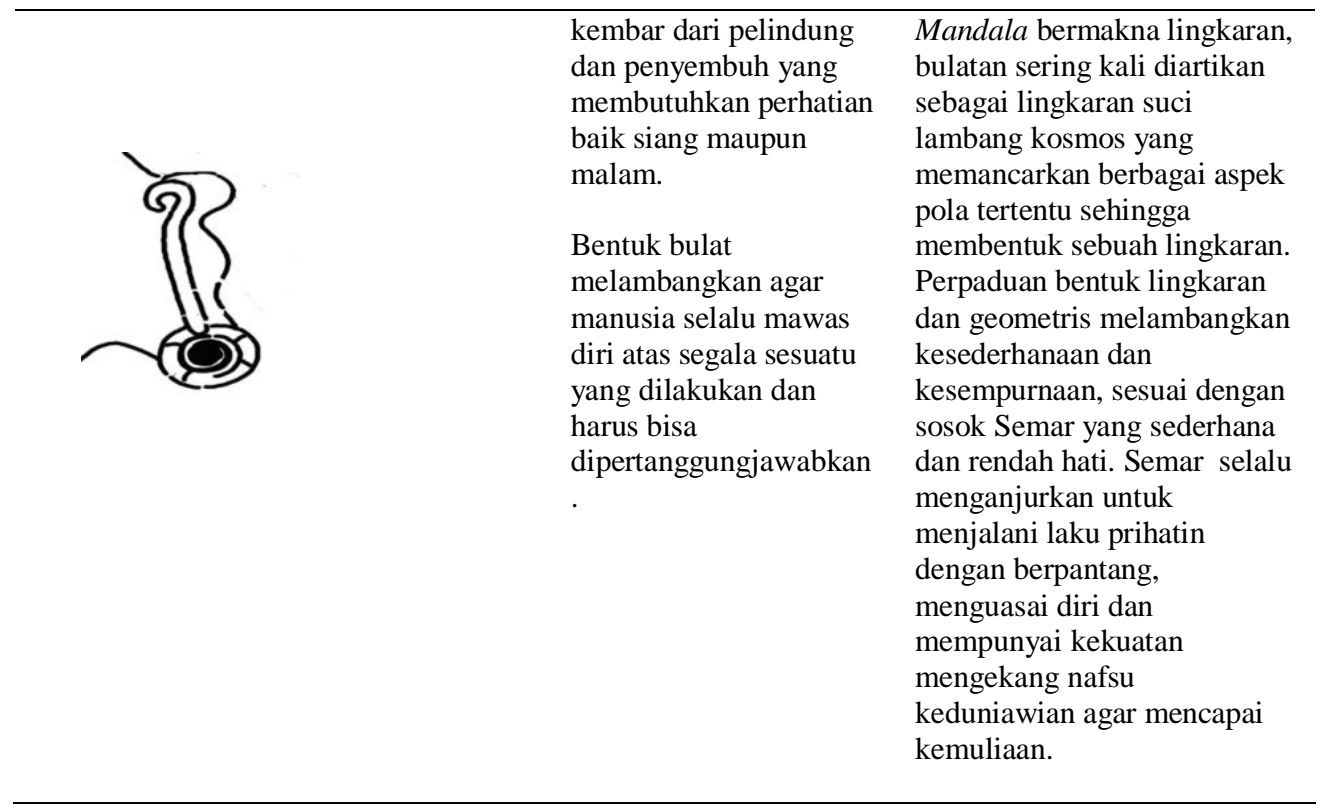

\section{$3 \quad$ Kesimpulan}

Pembuatan figurin gerabah Majapahit berkaitan dengan pertimbangan kaidahkaidah seni yang menyangkut unsur bentuk, makna dan simbolik. Pembuatan figurin didasarkan atas suatu perhitungan yang matang menyangkut teknik dan proses penggarapan. Figurin gerabah merupakan salah satu media yang digunakan untuk menyampaikan pesan-pesan atau ajaran moral (nilai-nilai keagamaan, kepahlawanan, kesetiaan dan cinta kasih) yang memiliki nilai komunikatif.

Bentuk dan makna simbolik figurin gerabah Majapahit mengacu pada kaidahkaidah dan unsur-unsur budaya yang berlaku pada masa itu, di antaranya: agama dan kepercayaan yang dianut oleh raja dan masyarakat. Keterkaitan ini tidak hanya merupakan penggarapan sebuah patung arca untuk memenuhi rasa kepuasaan, akan tetapi terkait dengan keperluan upacara keagamaan sebagai arca pendharmaan dan simbol sosial masyarakat juga sebagai boneka pertunjukkan. Sebagai salah satu unsur kebudayaan, figurin gerabah tidak terlepas dari pengaruh-pengaruh asing yang masuk dalam kebudayaan Majapahit. Figurin gerabah dikategorikan sebagai produk akulturasi. Hal ini dapat dilihat pada unsur-unsur pembentuk figurin gerabah Majapahit yang memiliki unsur-unsur percampuran dari beberapa kebudayaan seperti halnya kebudayaan Hindu dan Budha. 
Bentuk dan makna simbolik figurin gerabah Majapahit memiliki rangkaian yang terkait dengan budaya dalam kehidupan masyarakat. Keterkaitan ini dipengaruhi oleh faktor-faktor pendukung, yaitu agama yang dianut sebagian besar masyarakat, kepercayaan dan keyakinan akan adanya kekuatan gaib, adat istidat, kesenian dan latar belakang masyarakat. Dengan demikian figurin gerabah Majapahit sarat dengan seluruh sendi kehidupan masyarakat pendukungnya yang mencerminkan ketaatan dalam beragama.

\section{Referensi}

[1] Sedyawati, Edi, et al. 1992. Sejarah Kebudayaan Jawa. Jakarta: Depdikbud, Direktorat Sejarah dan Nilai Tradisional. 